\title{
The Effects of Ethephon on Saskatoon (Amelanchier alnifolia Nutt.) Fruit Ripening
}

\author{
Roisin McGarry, Jocelyn A. Ozga1, and Dennis M. Reinecke \\ Department of Agricultural, Food and Nutritional Science, University of Alberta, 4-10 Agriculturel \\ Forestry Centre, Edmonton, Alberta, Canada T6G 2 P5
}

ADDITIONAL INDEX WORDS. Amelanchier alnifolia, saskatoon, fruit ripening, fruit yield, fruit quality

\begin{abstract}
Field experiments were conducted on two cultivars of saskatoon to test the effectiveness of ethephon in stimulating uniform fruit ripening without compromising fruit quality. Shrubs of cultivars Northline and Smoky were sprayed to runoff with ethephon $\left(0,250,500\right.$, and $1000 \mathrm{mg} \cdot \mathrm{L}^{-1}$ for 'Northline'; 0,500 , and $1000 \mathrm{mg} \cdot \mathrm{L}^{-1}$ for ' $\mathrm{Smoky}$ ') prior to fruit maturity. Fruit were harvested 4 to 8 days after treatment and sorted into ripeness categories by size, and the fully ripe fruit were evaluated for quality (surface color, firmness, mean fruit weight, soluble solids, and titratable acids). Ethephon significantly increased the percent ripe fruit per shrub (by up to $9.7 \%$ ) in both cultivars, without a significant effect on fruit quality. At concentrations up to $1000 \mathrm{mg} \cdot \mathrm{L}^{-1}$, ethephon may be an effective ripening agent for saskatoon fruit without reducing fruit quality. Although there were significant differences in yield from year to year for both cultivars because of their biennial-bearing habit, ethephon treatments did not significantly affect total yields.
\end{abstract}

The saskatoon is an emerging North American fruit crop (StPierre, 1992) with widespread commercial potential. Somewhat similar to blueberry (Vaccinium angustifolium Ait.), it is nevertheless much better adapted to very cold winter temperatures and mildly alkaline soils (Finn, 1999). Most of the production occurs in the Prairie Provinces of Canada, with Alberta the current leader at 600 ha and 1.35 million $\mathrm{kg}$. Demand (both domestic and international) has been expanding and production (up 5-fold in Alberta since 1999) has kept pace, as young orchards planted years ago reach their bearing age (Jeffs, 2003). Roughly half of the Alberta crop is processed into syrups and other products, partly because the freshly picked fruit is highly perishable. The need for quality fruit (both for processing and fresh consumption) has facilitated the introduction of specialized mechanical harvesters to counteract the high cost of hand-picking. Unfortunately, the nonuniform ripening pattern exhibited by saskatoon fruit (Green and Mazza, 1986) makes it difficult to maximize the yield of salable fruit with once-over mechanical harvesting. Ethylene is a naturally occurring ripening hormone in many fruits (Burdon and Sexton, 1990; Gross and Sams, 1984; Iannetta et al., 1999; McGlasson, 1985). The effects of endogenous and exogenous ethylene on various fruit-quality parameters have been studied in crops like apple [Malus $\times$ sylvestris (L.) Mill. var. domestica (Borkh.) Mansf.] (Curry, 1994), grape (Vitis vinifera L.) (Powers et al., 1980; Roubelakis-Angelakis and Kliewer, 1986; Weaver and Montgomery, 1974), raspberry (Rubus idaeus L.) (Perkins and Nonnecke, 1992), and saskatoon (Rogiers and Knowles, 1997). However, the role of exogenous ethylene in influencing the time of ripening has been of particular interest to growers who rely heavily on once-over mechanical harvesters. Ethephon (2-chloroethylphosphonic acid) is an ethylene-releasing agent which has been used to synchronize ripening in a number of horticultural crops, including cherry (Prunus cerasus L.) (Olien and Bukovac, 1978), coffee (Coffea arabica L.) (Browning and

Received for publication 4 Mar. 2004. Accepted for publication 23 May 2004. We wish to thank Bob Hardin for help with the statistical analysis and Gabe Botar and Peter Blenis for helpful editing of this manuscript.

'To whom reprint requests should be addressed. E-mail address: jocelyn. ozga@ualberta.ca
Cannell, 1970; Winston et al., 1992), olive (Olea europaea L.) (Tous et al., 1995), pepper (Capsicum аппиит L.) (Batal and Granberry, 1982; Sims et al., 1974), and tomato (Lycopersicon esculentum Mill.) (Dostal and Wilcox, 1971). The objective of this study was to test the effectiveness of ethephon in stimulating uniform ripening of saskatoon fruit without negatively affecting fruit quality and yield.

\section{Materials and Methods}

Field experiments were conducted on mature 'Northline' and 'Smoky' saskatoon shrubs (all planted in 1988) during two seasons (1994 and 1995) at the Alberta Crop Diversification Centre North, Edmonton, Alberta, Canada. Three stands of each cultivar (three to five shrubs per stand) were selected for uniform shrub size. Four ethephon concentrations were applied to randomly selected 'Northline' shrubs $\left(0,250,500\right.$, and $1000 \mathrm{mg} \cdot \mathrm{L}^{-1}$; three shrubs per treatment) and three to randomly selected 'Smoky' shrubs $\left(0,500\right.$, and $1000 \mathrm{mg} \cdot \mathrm{L}^{-1}$; three shrubs per treatment). Ethephon solutions were prepared from a stock solution of 480 $\mathrm{g} \cdot \mathrm{L}^{-1}$ ethephon (Cerone; Union Carbide Agricultural Products Co., Calgary, Canada) diluted with distilled water ( $\mathrm{pH}$ 5.6) to obtain the desired concentrations $\left(250,500\right.$, and $\left.1000 \mathrm{mg} \cdot \mathrm{L}^{-1}\right)$; distilled water was used for the control $\left(0 \mathrm{mg} \cdot \mathrm{L}^{-1}\right)$ solutions. Each treated shrub was sprayed once with a compressed-air sprayer to runoff when $\approx 70 \%$ of the "berries" were red (maturity class \#7: Rogiers and Knowles, 1997) ['Northline' on 13 July 1994 (24.1 ${ }^{\circ} \mathrm{C}$ ), and 19 and $21 \mathrm{July} 1995\left(27.3^{\circ} \mathrm{C}\right.$ and $22.2^{\circ} \mathrm{C}$, respectively); 'Smoky' on 13 July $1994\left(24.1^{\circ} \mathrm{C}\right)$ and 13 July $1995\left(24.5^{\circ} \mathrm{C}\right)$ ]. Polyethylene baffles were erected between shrubs to prevent drift during application.

The saskatoon "berry" is actually a pome that may reach 20 $\mathrm{mm}$ or more in diameter when ripe; fruit size and shape vary among cultivars, but all commercial cultivars show a progression in fruit skin color from green through very dark purple as ripening proceeds. When $\approx 70 \%$ of the control berries were purple (maturity classes \#8 and \#9: Rogiers and Knowles, 1997) (4-8 d after treatment), fruit were harvested onto crushed ice ('Northline' on 19 July 1994, and 24 and 25 July 1995; 'Smoky' on 18 July 1994, and 19 and 21 July 1995). The total fruit per shrub or a 1-kg 
sample of harvested berries was sorted on ice into nine maturity classes grouped according to fruit size and surface color (Rogiers and Knowles, 1997): \#9 = mature, ripe, purple-blue fruit with average diameter of $14 \mathrm{~mm}$; \#8 = mature, purple-red fruit with average diameter of $14 \mathrm{~mm} ; \# 7=$ red fruit with diameter of 13 $\mathrm{mm} ; \# 6$ = pink fruit with diameter of $12 \mathrm{~mm}$; $\#$ = pink and white fruit with diameter of $11 \mathrm{~mm}$; $\#$ to $\# 1$ = green fruit, following in order of descending size (diameters of 11, 10, 9, and $7 \mathrm{~mm}$, respectively; Fig. 1). To ensure consistent sorting of berries into the appropriate maturity classes, fruit surface color was quantified through the specimen port of a HunterLab Color/Difference Meter D25/L2 (Hunter Laboratory Associates, Fairfax, Va.) which had been calibrated according to factory values for the white, black, blue, and pink tiles ( $\mathrm{L}, \mathrm{a}, \mathrm{b}$ values measured with $90^{\circ}$ rotations of each fruit-filled petri dish; three replications per treatment). The $\mathrm{L}$ value indicates darkness or lightness of color, ranging from complete darkness $(\mathrm{L}=0)$ to pure white light $(\mathrm{L}=100)$. The a and b values are coordinates that indicate color directions: $+a$ is the red direction, $-\mathrm{a}$ is the green direction, $+\mathrm{b}$ is the yellow direction, and $-\mathrm{b}$ is the blue direction. Chroma $(\mathrm{C}$; saturation or vividness of color) and hue angle $\left(\mathrm{h}^{\circ}\right.$; the basic tint of color) are derived from a and b and were calculated as described by McGuire (1992). As chromaticity increases, a color becomes more intense; as it decreases a color becomes more dull. For useful interpretation, $\mathrm{h}^{\circ}$ should remain positive between $0^{\circ}$ and $360^{\circ}$ of the color wheel. As such, $\mathrm{a} \mathrm{h}^{\circ}$ of $0^{\circ}$ is red-purple, $90^{\circ}$ is yellow, $180^{\circ}$ is bluish-green, and $270^{\circ}$ is blue (McGuire, 1992). As saskatoon fruit mature from stage 7 (red) to stage 9 (bluish-purple), the $\mathrm{h}^{\circ}$ values range from $20^{\circ}$ (red), through $0^{\circ}$ (red-purple), to $330^{\circ}$ (bluish-purple). For unbiased statistical analyses, 360 was added to $h^{\circ}$ values $<25^{\circ}$ when performing analysis of variance (ANOVA) and orthogonal polynomial contrasts on these data.
The fresh weight of fruit per shrub in each maturity class was determined gravimetrically. The "ripe fruit" per shrub comprised the combined weights of maturity classes \#8 and \#9 and was expressed as a percentage of the total fruit weight per shrub. Category \#9 fruit were used to obtain measurements for weight, firmness, soluble solids, and titratable acids.

Fresh-fruit firmness was determined using the 50-kg Kramer shear of the Instron Universal Testing System (model 4201; Instron Corp., Canton, Mass.) [13 fruit per replication; three replications (shrubs) per treatment].

Soluble solids concentration (SSC), expressed as percent sucrose equivalents, was determined using the refractometer method (AOAC, 2002a) with a Zeiss Abbe refractometer (Carl Zeiss Oberkochen,Wurtt, Germany) connected to a water bath $\left(20^{\circ} \mathrm{C}\right)$. Frozen fruit $(50 \mathrm{~g})$ was blended with $50 \mathrm{~mL}$ of distilled water for 3 min at high speed in a blender. The slurry was strained through two layers of cheesecloth, the liquid was centrifuged at $3500 g_{\mathrm{n}}$ for $5 \mathrm{~min}$, the collected supernatant was centrifuged again at $3500 g_{\mathrm{n}}$ for $5 \mathrm{~min}$, and the final supernatant was filtered through Whatman \#4 filter paper. The percent SSC was determined from the filtrate [three replications (shrubs) per treatment], and corrected for the initial dilution.

Titratable acidity (TA), expressed as percent malic acid equivalents, was determined using the glass-electrode method (AOAC, 2002b) used by Green and Mazza (1986). Frozen fruit (30 g) was blended with $30 \mathrm{~mL}$ of distilled water for $3 \mathrm{~min}$ at high speed in a blender. An additional $50 \mathrm{~mL}$ of distilled water was added, and the slurry was boiled for 30 min while replacing water lost to evaporation. The boiled fruit slurry was brought to a final volume of $200 \mathrm{~mL}$, strained through two layers of cheesecloth, and centrifuged at $14,000 \mathrm{~g}_{\mathrm{n}}$ for $5 \mathrm{~min}$; the supernatant was then filtered through Whatman \#4 filter paper. Aliquots of filtrate (25

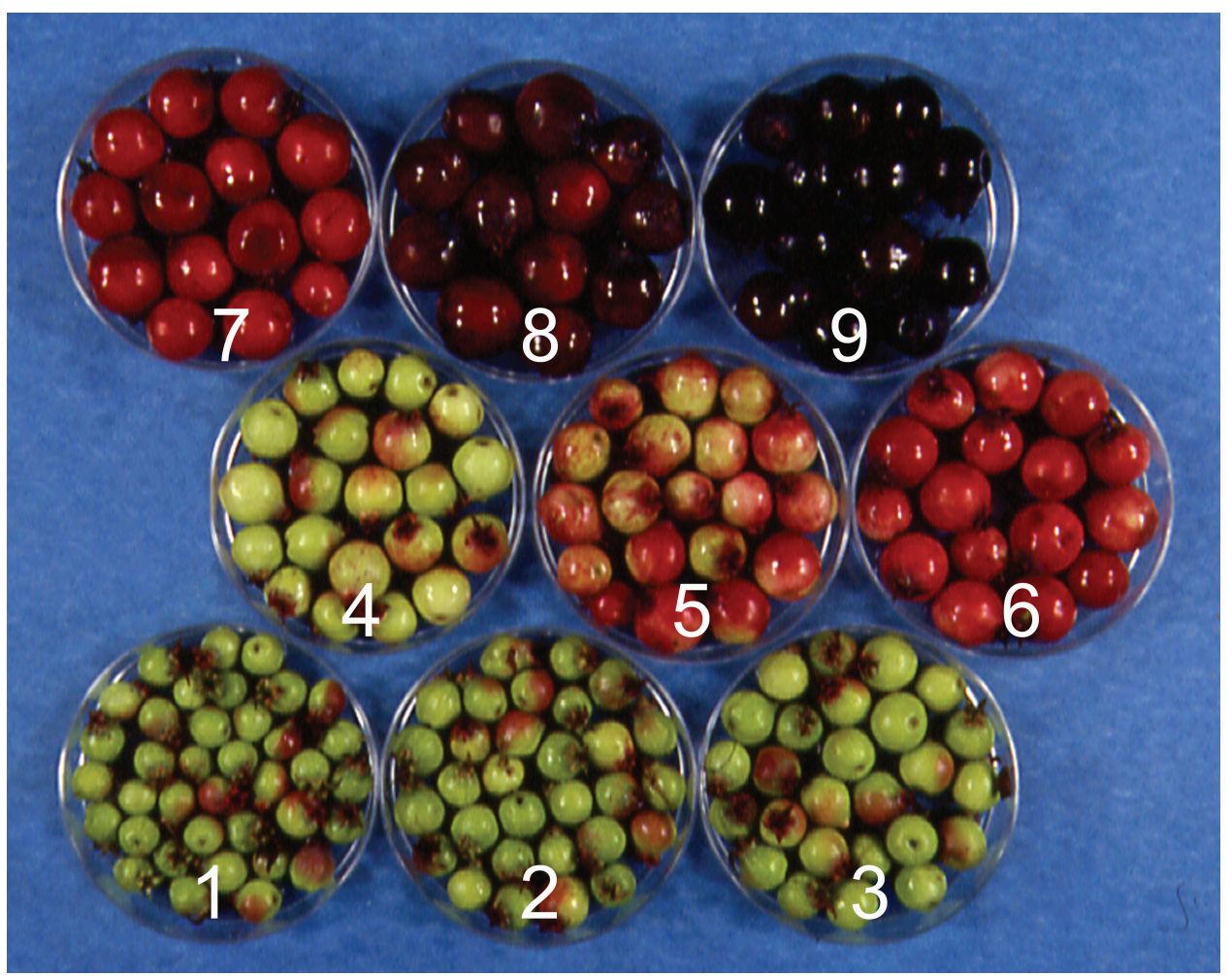

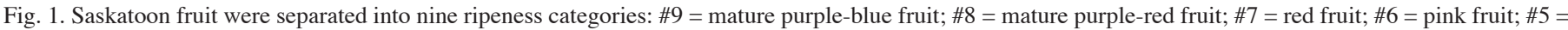
pink-and-white fruit; \#4 through \#1 = green fruit, in order of descending fruit size ('Northline'). 
$\mathrm{mL}$ ) were titrated past the end-point ( $\mathrm{pH} 8.1$ ) with $0.01 \mathrm{M} \mathrm{NaOH}$, and the volume of $0.1 \mathrm{~m} \mathrm{NaOH}$ required to titrate $100 \mathrm{~g}$ of fruit at the end-point was calculated. Malic acid equivalents were determined from fruit filtrate [three replications (shrubs) per treatment] and expressed as grams of acid per $100 \mathrm{~g}$ of fruit.

The ethephon experiment was set up as a split-split-plot experimental design within each of the two cultivars. The data were analyzed using ANOVA. The sources of variation were set as shrub origin (micropropagated plants vs. transplanted suckers) and stand number ( $\mathrm{s}=3$ ) nested within origin as the main plot, ethephon treatment as the split-plot, and year of treatment as the split-split plot.

Due to minimal yield of ripe fruit for 'Smoky' in 1994, only 1995 data were used to assess the effect of ethephon on the percent ripe fruit in this cultivar. These data were analyzed as a split-plot with sources of variation of origin and stands nested within origin as the main plot and ethephon treatment as the split-plot.

Orthogonal polynomial contrasts were used to determine if there were linear or quadratic trends in the dependent variables as a function of ethephon concentration.

The yield of the three control shrubs of 'Northline' and 'Smoky' were assessed in 1994, 1995, and 1996. These yield data were analyzed as a spilt-plot design with sources of variation of origin and stands within origin as the main plot and years as the split-plot.

For statistical analysis, the General Linear Model of the SAS 6.10 program (SAS Institute, Cary, N.C.) was used.

\section{Results}

When examined one cultivar at a time, the yield obtained from the control shrubs of 'Northline' and 'Smoky' varied significantly among years $(P \leq 0.01)$. In 'Northline', the total fruit yield per shrub was significantly less in 1994 and 1996 than in 1995 (Table 1; $P \leq 0.05$ ). In 'Smoky', the total fruit yield per shrub was significantly different each year, with the least amount of fruit harvested in 1994, and the most fruit collected in 1995 (Table $1 ; P \leq 0.05$ ). Ethephon did not significantly affect the yield from 'Northline' or 'Smoky' shrubs (Tables 2 and 3). Because of the minimal fruit yields obtained from 'Smoky' in 1994, the effect of ethephon on synchronizing ripening of 'Smoky' fruit was assessed in 1995 only.

Ethephon treatment significantly affected the percent ripe fruit per shrub in both cultivars (Fig. $2 ; P \leq 0.05$ ). In 'Northline', the percent ripe fruit per shrub increased with increasing ethephon concentration (Fig. 2; 1994 and 1995; linear trend significant, $P$ $\leq 0.01$ ), with a maximum increase of $7.5 \%$ attained with 1000 $\mathrm{mg} \cdot \mathrm{L}^{-1}$ ethephon. In 'Smoky', ethephon at $500 \mathrm{mg} \cdot \mathrm{L}^{-1}$ elicited the greatest increase $(9.7 \%$ ) in percent ripe fruit per shrub (Fig. 2; 1995; linear trend significant at $P=0.056$ and quadratic trend significant at $P \leq 0.03$ ).

Table 1. The fruit yields observed from 'Northline' and 'Smoky' saskatoon shrubs from 1994 to 1996.

\begin{tabular}{lccc}
\hline & \multicolumn{3}{c}{${\text { Yield }(\mathrm{kg} / \mathrm{shrub})^{\mathrm{z}}}$} \\
\cline { 2 - 4 } Cultivar & 1994 & 1995 & 1996 \\
\hline Northline & $2.90 \mathrm{~b}$ y & $7.74 \mathrm{a}$ & $3.45 \mathrm{~b}$ \\
Smoky & $0.32 \mathrm{z}$ & $10.14 \mathrm{x}$ & $2.09 \mathrm{y}$ \\
\hline
\end{tabular}

zYields obtained from control shrubs.

yMean separation within rows (ab)(xyz) by the least significant difference test (LSD), $P \leq 0.05$.
In 'Northline', the year of treatment significantly affected fruit color development (Hunter L, C, and $\mathrm{h}^{\circ}$ values), SSC, TA, and the ratio of SSC:TA (Table 2; $P \leq 0.01$ ). In 1994, the Hunter $\mathrm{L}$ values were lower, $\mathrm{C}$ values were higher, and tint of color $\left(\mathrm{h}^{\circ}\right)$ more reddish-purple (than bluish-purple) than in 1995 $(P \leq 0.01)$, indicating that fruit harvested in 1994 were darker, more intense, and more red-purple in color than fruit from 1995. Values for SSC and SSC:TA were significantly greater while TA values were significantly less in 1994 than in $1995(P \leq 0.01)$. The year $\times$ origin interaction was significant for SSC, TA, and SSC:TA (Table 2; $P \leq 0.05$ ). In 1994, the SSC and SSC:TA were greater in fruits from micropropagated plants than plants derived from suckers; no difference was observed in 1995 (Table 2; $P$ $\leq 0.05$ ). TA did not vary between origins in 1994; however, in 1995, TA was greater in fruit from micropropagated plants than from plants derived from suckers (Table 2; $P \leq 0.05$ ). In 'Northline', fruit firmness and fresh weight did not differ with respect to shrub origin or year of application (Table 2). Fruit firmness and $\mathrm{h}^{\circ}$ decreased with increasing ethephon concentration (linear trend significant, $P \leq 0.05$ ) indicating fruit softened slightly and became more bluish-purple as ethephon concentration increased. Ethephon treatment did not affect the color characteristic L and C values, fruit fresh weight, SSC, TA, or SSC:TA of 'Northline' fruit (Table 2).

In 'Smoky', the year of treatment significantly affected fruit color development (Hunter $\mathrm{L}, \mathrm{C}$, and $\mathrm{h}^{\circ}$ values), SSC, and SSC: TA (Table $3, P \leq 0.01$ ). The Hunter $\mathrm{L}, \mathrm{C}$, and $\mathrm{h}^{\circ}$ values were significantly greater in 1994 than in 1995, indicating that fruit harvested in 1994 were lighter, more intense, and more reddishpurple in color than fruit from $1995(P \leq 0.01)$. Values for SSC and SSC:TA were significantly greater in 1994 than in $1995(P$ $\leq 0.01$ ). In 'Smoky', fruit color characteristics, firmness, fresh weight, SSC, TA, and SSC:TA did not differ with respect to shrub origin (Table 3 ). Hunter b values and $\mathrm{h}^{\circ}$ decreased with increasing ethephon concentration indicating that the fruit tint of color became more bluish-purple with increasing ethephon concentration (linear trend significant, $P \leq 0.05$ ). Ethephon treatment did not affect the Hunter $\mathrm{L}$ and $\mathrm{C}$ values, firmness, fresh weight, SSC, TA, or SSC:TA of 'Smoky' fruit (Table 3).

\section{Discussion}

The climacteric nature of saskatoon fruit is now established (Rogiers et al., 1998; Rogiers and Knowles, 1999). Uniform fruit ripening, essential for efficient mechanical harvesting, has been enhanced in many other fruit crops with applications of ethephon. In this study, saskatoon shrubs of cultivars Northline and Smoky treated with ethephon at the $70 \%$ "red-berry" stage (maturity class \#7: Rogiers and Knowles, 1997) yielded greater proportions of ripe fruit per shrub with a single harvest. In general, the increases in ripe fruit were small (6\% to $7 \%$ ) but significant for both cultivars tested. Based on saskatoon industry information from Alberta Agriculture, Food and Rural Development (1998) and updated to 2003, a $4 \%$ estimated net increase in income for a 4-ha orchard would be realized as a result of ethephon application (assuming 5\% increase in percent ripe fruit).

The success of ethephon in stimulating fruit ripening in field applications can be affected by numerous factors other than the cultivar (Bal etal., 1992; Cantliffe and Goodwin, 1975; Conrad and Sundstrom, 1987), including the stage of crop maturity (Cantliffe and Goodwin, 1975; Conrad and Sundstrom, 1987; Winston et al., 1992), the concentration of ethephon (Bal et al., 1992; Cantliffe 
Table 2. The effects of ethephon treatment, year of application, and plant origin on fruit yield and quality parameters were determined for 'Northline' saskatoon. ${ }^{\mathrm{z}}$

\begin{tabular}{|c|c|c|c|c|c|c|c|c|c|c|c|c|}
\hline \multirow[b]{2}{*}{ Year } & \multirow{2}{*}{$\begin{array}{c}\text { Treatment } \\
\left(\mathrm{mg} \cdot \mathrm{L}^{-1}\right)\end{array}$} & \multirow{2}{*}{$\begin{array}{c}\text { Yield } \\
\mathrm{kg} / \mathrm{shrub}\end{array}$} & \multirow{2}{*}{$\begin{array}{c}\text { Fruit } \\
\text { firmness } \\
\left(\mathrm{kg} \cdot \mathrm{g}^{-1}\right)\end{array}$} & \multirow{2}{*}{$\begin{array}{l}\text { Fruit } \\
\text { fresh } \\
\mathrm{wt}(\mathrm{g})\end{array}$} & \multirow{2}{*}{$\begin{array}{l}\mathrm{SSC}^{\mathrm{x}} \\
(\%)\end{array}$} & \multirow{2}{*}{$\begin{array}{c}\mathrm{TA}^{\mathrm{y}} \\
(\% \text { malic acid } \\
\text { equivalents) }\end{array}$} & \multirow[b]{2}{*}{ SSC:TA } & \multicolumn{5}{|c|}{ Color characteristicsw } \\
\hline & & & & & & & & $\mathrm{L}$ & $\mathrm{a}$ & $\mathrm{b}$ & $\mathrm{C}$ & $\mathrm{h}^{\circ}$ \\
\hline \multirow[t]{5}{*}{$\overline{1994}$} & 0 & 2.90 & 18.3 & 1.18 & 15.9 & 0.374 & 42.7 & 16.3 & 6.61 & 1.57 & 6.8 & 13.1 \\
\hline & 250 & 1.67 & 17.5 & 1.10 & 15.5 & 0.371 & 41.9 & 15.9 & 7.23 & 1.63 & 7.4 & 12.6 \\
\hline & 500 & 1.79 & 17.7 & 1.21 & 15.9 & 0.401 & 40.3 & 15.9 & 7.03 & 1.60 & 7.2 & 12.8 \\
\hline & 1000 & 2.58 & 16.6 & 1.18 & 15.4 & 0.368 & 41.6 & 15.8 & 7.42 & 1.45 & 7.6 & 11.0 \\
\hline & mean & $2.23 \mathrm{a}^{\mathrm{v}}$ & $17.5 \mathrm{~b}$ & $1.17 \mathrm{~b}$ & $15.7 \mathrm{a}$ & $0.379 \mathrm{a}$ & $41.6 \mathrm{a}$ & $16.0 \mathrm{a}$ & $7.08 \mathrm{a}$ & $1.56 \mathrm{a}$ & $7.3 \mathrm{a}$ & $12.4 \mathrm{a}$ \\
\hline \multirow{5}{*}{1995} & 0 & 7.74 & 18.0 & 1.13 & 13.6 & 0.507 & 27.2 & 16.0 & 1.90 & -0.72 & 2.0 & 339.8 \\
\hline & 250 & 6.04 & 18.3 & 1.15 & 14.4 & 0.559 & 26.5 & 18.6 & 2.17 & -1.00 & 2.4 & 336.0 \\
\hline & 500 & 7.27 & 18.5 & 1.13 & 14.1 & 0.520 & 27.0 & 18.3 & 2.25 & -1.00 & 2.5 & 335.4 \\
\hline & 1000 & 5.86 & 17.9 & 1.18 & 13.8 & 0.495 & 28.8 & 19.0 & 2.15 & -1.05 & 2.4 & 334.1 \\
\hline & mean & $6.73 \mathrm{~b}$ & $18.2 \mathrm{~b}$ & $1.15 \mathrm{~b}$ & $14.0 \mathrm{~b}$ & $0.518 \mathrm{~b}$ & $27.4 \mathrm{~b}$ & $18.7 \mathrm{~b}$ & $2.12 \mathrm{~b}$ & $-0.94 \mathrm{~b}$ & $2.3 \mathrm{~b}$ & $336.3 \mathrm{~b}$ \\
\hline \multirow[t]{2}{*}{$\begin{array}{l}\text { Micro- } \\
\text { propagated }\end{array}$} & 1994 mean & 1.62 & 17.4 & 1.17 & $16.5 \mathrm{a}^{\mathrm{u}}$ & $0.367 \mathrm{c}$ & $44.9 \mathrm{a}$ & 16.1 & 6.90 & 1.54 & 7.1 & 12.5 \\
\hline & 1995 mean & 6.00 & 18.1 & 1.11 & $13.7 \mathrm{c}$ & $0.540 \mathrm{a}$ & $25.6 \mathrm{c}$ & 19.0 & 2.18 & -0.99 & 2.4 & 336.0 \\
\hline \multirow[t]{2}{*}{ Sucker } & 1994 mean & 2.85 & 17.6 & 1.18 & $14.8 \mathrm{~b}$ & $0.390 \mathrm{c}$ & $38.3 \mathrm{~b}$ & 15.9 & 7.25 & 1.58 & 7.4 & 12.2 \\
\hline & 1995 mean & 7.46 & 18.3 & 1.18 & $14.3 \mathrm{c}$ & $0.498 \mathrm{~b}$ & $29.0 \mathrm{c}$ & 18.4 & 2.05 & -0.89 & 2.2 & 336.7 \\
\hline
\end{tabular}

${ }^{2}$ Quality parameters determined on stage 9 maturity fruits.

yTA = titratable acidity.

${ }^{x} \mathrm{SSC}=$ soluble solids concentration

${ }^{\mathrm{w}}$ Color measurements of L (lightness of color), C (chroma, saturation or vividness of color), and $\mathrm{h}^{\circ}$ (hue angle, tint of color; $0^{\circ}=$ red-purple, $90^{\circ}$ $=$ yellow, $180^{\circ}=$ bluish-green, $270^{\circ}=$ blue); $\mathrm{C}$ and $\mathrm{h}^{\circ}$ calculated from a and $\mathrm{b}$ values as described by McGuire (1992).

vMeans followed by different letters $(\mathrm{a}, \mathrm{b})$ indicate significant difference between years by analysis of variance, $P \leq 0.01$.

uMean separation within origin (abc) by least significant difference test (LSD), $P \leq 0.05$.

Table 3. The effects of ethephon treatment, year of application, and plant origin on fruit yield and quality parameters were determined for 'Smoky' saskatoon. ${ }^{\mathrm{z}}$

\begin{tabular}{|c|c|c|c|c|c|c|c|c|c|c|c|c|}
\hline \multirow[b]{2}{*}{ Year } & \multirow{2}{*}{$\begin{array}{c}\text { Treatment } \\
\left(\mathrm{mg} \cdot \mathrm{L}^{-1}\right)\end{array}$} & \multirow{2}{*}{$\begin{array}{c}\text { Yield } \\
\text { kg/shrub }\end{array}$} & \multirow{2}{*}{$\begin{array}{c}\text { Fruit } \\
\text { firmness } \\
\left(\mathrm{kg} \cdot \mathrm{g}^{-1}\right)\end{array}$} & \multirow{2}{*}{$\begin{array}{l}\text { Fruit } \\
\text { fresh } \\
\text { wt }(g)\end{array}$} & \multirow{2}{*}{$\begin{array}{l}\mathrm{SSC}^{\mathrm{x}} \\
(\%)\end{array}$} & \multirow{2}{*}{$\begin{array}{c}\text { TAy } \\
\text { (\% malic acid } \\
\text { equivalents) }\end{array}$} & \multirow[b]{2}{*}{ SSC:TA } & \multicolumn{5}{|c|}{ Color characteristics ${ }^{\mathrm{w}}$} \\
\hline & & & & & & & & $\mathrm{L}$ & $\mathrm{a}$ & $\mathrm{b}$ & $\mathrm{C}$ & $\mathrm{h}^{\circ}$ \\
\hline \multirow[t]{3}{*}{$\overline{1994}$} & 0 & 0.324 & --- & --- & 17.6 & 0.190 & 93.4 & 17.2 & 7.17 & -0.72 & 7.2 & 354.4 \\
\hline & 1000 & 0.365 & --- & --- & 18.4 & 0.236 & 75.1 & 16.9 & 7.12 & -1.12 & 7.2 & 351.1 \\
\hline & mean & $0.510 \mathrm{a}^{\mathrm{v}}$ & --- & --- & $17.4 \mathrm{a}$ & $0.218 \mathrm{~b}$ & $79.7 \mathrm{a}$ & $16.8 \mathrm{a}$ & $7.38 \mathrm{a}$ & $-0.92 \mathrm{a}$ & $7.45 \mathrm{a}$ & $352.9 \mathrm{a}$ \\
\hline \multirow[t]{2}{*}{1995} & 0 & 10.12 & 13.1 & 1.09 & 13.4 & 0.275 & 48.8 & 15.5 & 2.70 & -0.47 & 2.8 & 350.5 \\
\hline & mean & $9.37 \mathrm{~b}$ & 13.2 & 1.07 & $13.4 \mathrm{~b}$ & $0.257 \mathrm{~b}$ & $53.3 \mathrm{~b}$ & $15.5 \mathrm{~b}$ & $2.66 \mathrm{~b}$ & $-0.53 \mathrm{~b}$ & $2.73 \mathrm{~b}$ & $348.8 \mathrm{~b}$ \\
\hline \multirow[t]{2}{*}{$\begin{array}{l}\text { Micro- } \\
\text { propagated }\end{array}$} & 1994 mean & 0.324 & --- & --- & 17.9 & 0.228 & 73.7 & 17.6 & 7.17 & -0.86 & 7.23 & 353.3 \\
\hline & 1995 mean & 8.79 & 13.3 & 1.05 & 13.3 & 0.267 & 50.1 & 16.0 & 2.43 & -0.32 & 2.47 & 352.0 \\
\hline Sucker & 1994 mean & 0.695 & --- & --- & 16.8 & 0.208 & 85.7 & 16.1 & 7.60 & -0.99 & 7.67 & 352.5 \\
\hline
\end{tabular}

${ }^{\mathrm{z}}$ Quality parameters determined on stage 9 maturity fruits.

yTA = titratable acidity.

${ }^{\times} \mathrm{SSC}=$ soluble solids concentration.

${ }^{w}$ Color measurements of L (lightness of color), C (chroma, saturation or vividness of color), and $\mathrm{h}^{\circ}$ (hue angle, tint of color; $0^{\circ}=$ red-purple, $90^{\circ}$ $=$ yellow, $180^{\circ}=$ bluish-green, $270^{\circ}=$ blue); $\mathrm{C}$ and $\mathrm{h}^{\circ}$ calculated from a and $\mathrm{b}$ values as described by McGuire (1992).

vMeans followed by different letters $(\mathrm{a}, \mathrm{b})$ indicate significant difference between years by analysis of variance, $P \leq 0.01$.

and Goodwin, 1975; Conrad and Sundstrom, 1987), the number of ethephon applications (Cantliffe and Goodwin, 1975; Conrad and Sundstrom, 1987), and the orchard temperature during (Bal et al., 1992) and after (Cantliffe and Goodwin, 1975; Conrad and Sundstrom, 1987; Olien and Bukovac, 1978) ethephon treatment. Our results indicate that applying ethephon to saskatoon shrubs when $\approx 70 \%$ of the berries are red can significantly increase the ripe fruit per shrub. Further experimentation will be required to test the effects of ethephon applied at earlier stages of saskatoon fruit development. However, since the majority of the fruit size (mass and volume) in saskatoon is obtained during the last 2 weeks of development (McGarry et al., 1998), only a relatively small time window of application is possible without a dramatic reduction in fruit size and quality.

At elevated concentrations, the effectiveness of ethephon as a fruit-ripening agent diminishes, and ethephon instead stimulates excessive fruit abscission (Batal and Granberry, 1982; Cantliffe and Goodwin, 1975; Conrad and Sundstrom, 1987; Cooksey et al., 


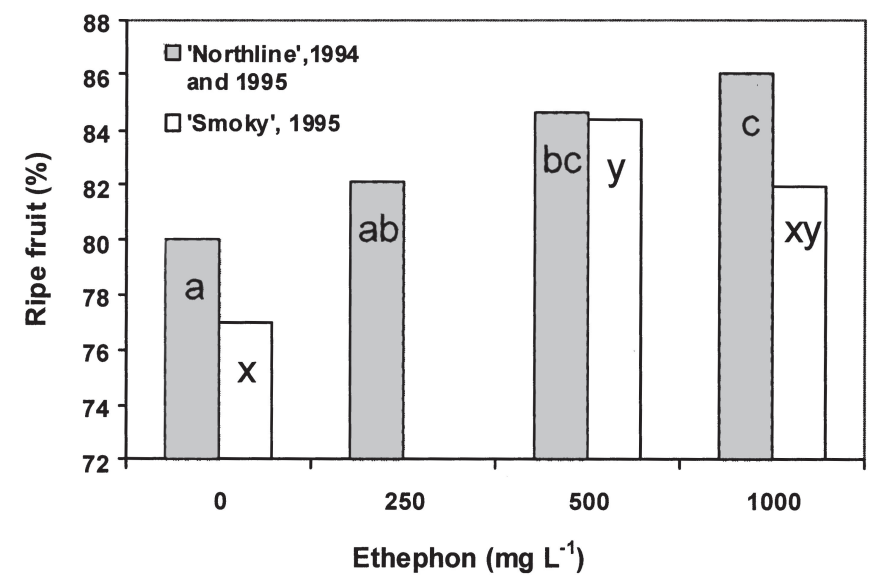

Fig. 2. The effect of ethephon on the percent of ripe fruit was determined for saskatoons 'Northline' (1994 and 1995) and 'Smoky' (1995). Mean separation among treatments was determined by the least significant difference test (LSD), $P \leq 0.05$, for 'Northline' (abc) and 'Smoky' (xy)

1994; Knavel and Kemp, 1973), defoliation (Batal and Granberry, 1982; Cantliffe and Goodwin, 1975; Conrad and Sundstrom, 1987; Cooksey et al., 1994; Martin et al., 1980), and accentuated alternate bearing (Wood, 1989). Thus premature fruit abscission occurs in pimiento and paprika peppers (Capsicum annuum L.) treated with 1500 to $3000 \mathrm{mg} \cdot \mathrm{L}^{-1}$ ethephon (Batal and Granberry, 1982), in tabasco peppers (Capsicum frutescens L.) sprayed with 5000 to $15,000 \mathrm{mg} \cdot \mathrm{L}^{-1}$ ethephon (Conrad and Sundstrom, 1987), and in olive treated with $2250 \mathrm{mg} \cdot \mathrm{L}^{-1}$ ethephon (Hartmann et al., 1970). Pecan [Carya illinoinensis (Wangenh.) C. Koch] trees suffer premature defoliation after exposure to $2000 \mathrm{mg} \cdot \mathrm{L}^{-1}$ ethephon (Martin et al., 1980). In 'Northline' and 'Smoky', ethephon (up to $1000 \mathrm{mg} \cdot \mathrm{L}^{-1}$ ) did not significantly stimulate the abscission of fruits. Testing of other saskatoon cultivars for ethephon-stimulated fruit abscission would be of value as they may differ in sensitivity to ethephon at the time of treatment.

With respect to saskatoon fruit quality (stage 9 maturity fruit), a small decrease in fruit firmness (in 'Northline') and a change in the tint of color $\left(\mathrm{h}^{\circ}\right)$ of the fruit from reddish-purple to bluishpurple (in both cultivars) with increasing ethephon concentration was observed. Ethephon treatments did not affect the fruit fresh weight, SSC, TA, or SSC:TA values in 'Northline' or 'Smoky'. This suggests that ethephon applications at concentrations up to $1000 \mathrm{mg} \cdot \mathrm{L}^{-1}$ may enhance saskatoon fruit ripening without reducing fruit quality. Fruit flavor is attributed to the ratio of SSC:TA (Young et al., 1993). The SSC, TA, and SSC:TA values differed between 1994 and 1995, likely reflecting seasonal variations. However, the mean SSC, TA, and SSC:TA values across years ('Northline': $14.8 \%$ SSC, $0.45 \%$ malic acid, 34.7, respectively; 'Smoky': 15.4\% SSC, 0.24\% malic acid, 64.3, respectively) were very similar to those values reported by Green and Mazza (1986) ('Northline': $16.1 \%$ SSC, $0.45 \%$ malic acid, 35.5, respectively; 'Smoky': $16.3 \%$ SSC, $0.25 \%$ malic acid, 66.2, respectively). In general, these data show that fruit from 'Northline' and 'Smoky' contained similar quantities of sugars (SSC). The higher SSC:TA from 'Smoky' fruit in 1994 and 1995 was attributed to the reduced amount of acids (TA) present, in contrast to 'Northline' fruit.

The total fruit per shrub in cultivars 'Northline' and 'Smoky' varied significantly between years. In both cultivars, yields alternated in a typical biennial-bearing pattern. Analysis of fruit production in subsequent seasons will be required to establish the extent of biennial bearing in these cultivars. It will also be useful to evaluate the effect of ethephon treatments on alternate bearing. Indeed, further studies will be necessary to characterize the degree to which alternate bearing may be expressed in and influenced by ethephon in other saskatoon cultivars. Finally, the origin of the bearing shrubs (micropropagated plants vs. suckers) may interact differently with ethephon treatments in cultivars other than those studied here; if so, the commercial implications could be significant.

In summary, ethephon treatment promoted uniform ripening in saskatoon cultivars Northline and Smoky. The increase in percent ripe fruit per shrub obtained from each cultivar was small but significant. Ethephon treatment did not adversely affect saskatoon fruit quality, as determined by surface color, fruit firmness, fresh weight, soluble solids concentration, titratable acidity, or the ratio of soluble solid concentration to titratable acidity. Therefore, ethephon could be a potentially effective ripening agent for saskatoon fruits.

\section{Literature Cited}

Alberta Agriculture, Food and Rural Development. 1998. Commercial saskatoon berry industry. Agdex 238/830-1. AAFRD, Edmonton, Canada.

AOAC International. 2002a. Fruits and fruit products, p. 7; 37.1.15. AOAC official method 932.12. In: W. Horwitz (ed.). Official methods of analysis of AOAC Intl., 17th ed., vol. II. Food composition; additives; natural contaminants. AOAC Intl., Gaithersburg, Md.

AOAC International. 2002b. Fruits and fruit products, p. 11; 37.1.37. AOAC official method 942.15. In: W. Horwitz (ed.). Official methods of analysis of AOAC Intl., 17th ed., vol. II. Food composition; additives; natural contaminants. AOAC Intl., Gaithersburg, Md.

Bal, J.S., M.P. Singh, P.P.S. Minhas, and A.S. Bindra. 1992. Effect of ethephon on ripening and quality of papaya. Acta Hort. 296:119-122.

Batal, K.M. and D.M. Granberry. 1982. Effects of growth regulators on ripening and abscission of pimiento and paprika peppers. HortScience 17:944-946.

Browning, G. and M.G.R. Cannell. 1970. Use of 2-chloroethane phosphonic acid to promote the abscission and ripening of fruit of Coffea arabica L. J. Hort. Sci. 45:223-232.

Burdon, J.N. and R. Sexton. 1990. The role of ethylene in the shedding of red raspberry fruit. Ann. Bot. 66:111-120.

Cantliffe, D.J. and P. Goodwin. 1975. Red color enhancement of pepper fruits by multiple applications of ethephon. J. Amer. Soc. Hort. Sci. 100:157-161.

Conrad, R.S. and F.J. Sundstrom. 1987. Calcium and ethephon effects on tabasco pepper leaf and fruit retention and fruit color development. J. Amer. Soc. Hort. Sci. 112:424-426.

Cooksey, J.R., B.A. Kahn, and J.E. Motes. 1994. Calcium and ethephon effects on paprika pepper fruit retention and fruit color development. HortScience 29:792-794.

Curry, E.A. 1994. Preharvest applications of ethephon reduce superficial scald of Fuji and Granny Smith apples in storage. J. Hort. Sci. 69:1111-1116.

Dostal, H.C. and G.E. Wilcox. 1971. Chemical regulation of fruit ripening of field-grown tomatoes with (2-chloroethyl)phosphonic acid. J. Amer. Soc. Hort. Sci. 96:656-660.

Finn, C. 1999. Temperate berry crops, p. 324-334 in: J. Janick (ed.). Perspectives on new crops and new uses. ASHS Press, Alexandria, Va.

Green, R.C. and G. Mazza. 1986. Relationships between anthocyanins, total phenolics, carbohydrates, acidity, and color of saskatoon berries. Can. Inst. Food Sci. Technol. J. 19:107-113.

Gross, K.C. and C.E. Sams. 1984. Changes in cell wall neutral sugar composition during fruit ripening: A species survey. Phytochemistry 23:2457-2462.

Hartmann, H.T., A. Tombesi, and J. Whisler. 1970. Promotion of ethylene 
evolution and fruit abscission in the olive by 2-chloroethanephosphonic acid and cycloheximide. J. Amer. Soc. Hort. Sci. 95:635-640.

Iannetta, P.P.M., J. van den Berg, R.E. Wheatley, R.J. McNicol, and H.V. Davies. 1999. The role of ethylene and cell wall modifying enzymes in raspberry (Rubus idaeus) fruit ripening. Physiol. Plant. 105:338-347.

Jeffs, A. 2003. Secret's out on saskatoons. Edmonton J. 26 July 2003. p. H1. CanWest Publ., Edmonton, Canada.

Knavel, D.E. and T.R. Kemp. 1973. Ethephon and CPTA on color development in bell pepper fruits. HortScience 85:403-404.

Martin, G.C., R.C. Campbell, and R.M. Carlson. 1980. Effect of calcium in offsetting defoliation induced by ethephon in pecan. J. Amer. Soc. Hort. Sci. 105:34-37.

McGarry, R., J.A. Ozga, and D.M. Reinecke. 1998. Patterns of saskatoon (Amelanchier alnifolia Nutt.) fruit and seed growth. J. Amer. Soc. Hort. Sci. 123:26-29.

McGlasson, W.B. 1985. Ethylene and fruit ripening. HortScience 20:51-54

Olien, W.C. and M.J. Bukovac. 1978. The effect of temperature on rate of ethylene evolution from ethephon and from ethephon-treated leaves of sour cherry. J. Amer. Soc. Hort. Sci. 103:199-202.

Perkins, V.P. and G. Nonnecke. 1992. Physiological changes during ripening of raspberry fruit. HortScience 27:331-333.

Powers, J.R., E.A. Shively, and C.W. Nagel. 1980. Effect of ethephon on color of 'Pinot Noir' fruit and wine. Amer. J. Enol. Viticult. 31:203-205.

Rogiers, S.Y. and N.R. Knowles. 1997. Physical and chemical changes during growth, maturation, and ripening of saskatoon (Amelanchier alnifolia) fruit. Can. J. Bot. 75:1215-1225.
Rogiers, S.Y. and N.R. Knowles. 1999. A comparison of preharvest and postharvest ethylene production and respiration rates of saskatoon (Amelanchier alnifolia Nutt.) fruit during development. Can. J. Bot. 77:323-332.

Rogiers, S.Y., G.N. Mohan Kumar, and N.R. Knowles. 1998. Regulation of ethylene production and ripening by saskatoon (Amelanchier alnifolia Nutt.) fruit. Can. J. Bot. 76:1743-1754.

Roubelakis-Angelakis, K.A. and W.M. Kliewer. 1986. Effects of exogenous factors on anthocyanin and total phenolics in grape berries. Amer. J. Enol. Viticult. 37:275-280.

Sims, W.L., D. Ririe, R.A. Brendler, M.J. Snyder, D.N. Wright, V.H. Schweers, and P.P. Osterli. 1974. Factors affecting ethephon as an aid in fruit ripening of peppers. Calif. Agr., 3-4 June.

St-Pierre, R.G. 1992. The development of native fruit species as horticultural crops in Saskatchewan. HortScience 27:866.

Tous, J., J. Lloveras, and A. Romero. 1995. Effect of ethephon spray treatments on mechanical harvesting and oil composition on 'Arbequina' olives. J. Amer. Soc. Hort. Sci. 120:558-561.

Weaver, R.J. and R. Montgomery. 1974. Effect of ethephon on coloration and maturation of wine grapes. Amer. J. Enol. Viticult. 25:39-41.

Winston, E.C., M. Hoult, C.J. Howitt, and R.K. Shepherd. 1992. Ethylene-induced fruit ripening in arabica coffee (Coffea arabica L.). Austr. J. Expt. Agr. 32:401-408.

Wood, B.W. 1989. Ethephon and NAA facilitate early harvesting of pecans. J. Amer. Soc. Hort. Sci. 114:279-282.

Young, T.E., J.A. Juvik, and J.G. Sullivan. 1993. Accumulation of the components of total solids in ripening fruit of tomato. J. Amer. Soc. Hort. Sci. 118:286-292. 